\title{
CENTRAL BANKING AND THE CHOICE OF CURRENCY REGIME IN ACCESSION COUNTRIES
}

\author{
Willem H. Buiter* \\ Chief Economist, European Bank for Reconstruction and Development \\ and \\ Clemens Grafe \\ Economist, European Bank for Reconstruction and Development
}

Société Universitaire Européenne de Recherches Financières

Vienna 2001

\footnotetext{
* The views and opinions expressed are those of the authors. They do not necessarily represent the views and opinions of the European Bank for Reconstruction and Development. We would like to thank Ricardo Lago and participants at the SUERF seminar in Warsaw, Poland, on 26 October 2000, for helpful comments.
} 
Willem H. Buiter and Clemens Grafe

Central Banking and the Choice of Currency Regime in Accession Countries Vienna: SUERF (SUERF Studies: 11)

ISBN 3-902109-03-3

JEL: E58 (Central Banks and Their Policies), E52 (Monetary Policy (Targets, Instruments and Effects)), F15 (Financial Integration), F33 (International Monetary Arrangements and Institutions).

\section{(C) 2001 SUERF, Vienna}

Copyright reserved. Subject to the exception provided for by law, no part of this publication may be reproduced and/or published in print, by photocopying, on microfilm or in any other way without the written consent of the copyrightholder(s); the same applies to whole or partial adaptions. The publisher retains the sole right to collect from third parties fees payable in respect of copying and/or take legal or other actions for this purpose. 


\begin{abstract}
The subject matter of this paper is the design of appropriate Central Banking arrangements and exchange rate regimes for those former centrally planned Central and East European countries that are candidates for full membership in the European Union. We give an overview of the existing arrangements and point out to which extent monetary arrangements are restricted by conditions for entry both into the European Union and eventually into the European Monetary Union. Furthermore we investigate to which degree countries are fulfilling the accession criteria and compare their performance with the performance of earlier EU joiners like the countries of the Iberian Peninsula, Ireland and Greece.

After concluding that the accession criteria do not necessarily favour a particular monetary regime, we analyse the pros and cons of the two regimes widely believed to be most stable: currency boards and inflation targeting. We find that under either regime tensions are likely to arise from the attempt to meet the accession criteria of a low inflation rate and a stable exchange rate. Due to likely large productivity gains in the traded goods sector the real exchange rate can be expected to display a trend appreciation. Thus a currency board arrangement may well fail to produce an inflation rate below the Maastricht ceiling, unless the economy is run with a wasteful amount of spare capacity. Similarly the credibility of any inflation target would be undermined by the requirement that the exchange rate be kept within a specified target zone. This conflict could be resolved if the inflation ceiling was re-specified in terms of traded goods price inflation (and preferable in terms of 'core' traded goods price inflation) but this would require a change in the Maastricht Treaty.
\end{abstract}




\section{Contents}

I. Introduction

II. Monetary and Exchange Rate Regimes in Accession Countries: Current Practice

III. Monetary and Exchange Rate Regimes in Accession Countries: the Optimal Currency Area Perspective

IV. Currency Board or Floating-cum-Inflation Targeting: Which one dominates?

V. Balassa-Samuelson meets the EMU Inflation and Exchange Rate Criteria

VI. The Euro as Parallel Currency for Accession Countries

VII. Conclusion: Is Inflation Targeting a Better Opinion for Accession Countries Than a Currency Board? 


\section{Introduction}

The subject matter of this paper is the design of appropriate Central Banking arrangements and exchange rate regimes for those former centrally planned Central and East European countries that are candidates for full membership in the European Union. There are ten countries in the Group of 'official' candidate countries - the thirteen countries for whom the process that will make EU enlargement possible was launched by the EU in March 1998: ${ }^{1}$ Bulgaria, the Czech Republic, Estonia, Hungary, Latvia, Lithuania, Poland, Romania, the Slovak Republic and Slovenia.

The original two-tier system had a first group containing the Czech Republic, Estonia, Hungary, Poland and Slovenia which was expected to join the EU first (henceforth Group 1), and a second group containing Bulgaria, Latvia, Lithuania, Romania and the Slovak Republic (henceforth Group 2) ${ }^{2}$. Following the November 1999 Helsinki summit, the two-tier system was abandoned and replaced by an informal 'queue'. Individual candidates for accession could advance or fall back, depending on their success in implementing the 'Acquis Communautaire' and satisfying the other conditions for entry. There is no longer any presumption that countries will enter as a group. In addition, there are countries like Croatia, which currently are not on the list of official EU accession candidates but which, on current transition form, are quite likely to become full EU members before some of the countries that are on that list like Romania which regressed during 2000 as regards the 'Acquis'.

As regards likely accession dates, there is no longer any prospect of any of the front runners joining on January 1, 2003, the date envisaged, or at any rate aspired to, by some of them. It remains a possibility that the first accessions take place in January 2004, but January 2005 seems a safer bet. Further delays are certainly possible, as enlargement has effectively been made contingent on the success of internal reforms in the EU. Key required institutional reforms include such contentious issues as the scope of the national veto, the rules (including the weighting of the national votes) governing qualified

\footnotetext{
${ }^{1}$ The three other official candidates are Cyprus, Malta and Turkey.

${ }^{2}$ Cyprus was the sixth member of this group.
} 
majority voting, and the size of the Commission. Critical substantive reforms include the Reform of the Common Agricultural Policy. The EU's Intergovernmental Conference of December 2000 in Nice failed to reform EU institutions to the point that they might be workable in a Union of up to 25 members. The next serious attempt to create workable EU institutions has been put off till 2004.

The exact meaning of membership for the candidate accession countries is becoming less clear. There are likely to be lengthy transition periods in such areas as labour mobility and the environmental acquis. There have recently been suggestions both that, as part of a multi-speed EU, different incumbent members could treat any given new member differently, and that any given incumbent member might accord different treatment to different new members. As Berglof and Roland [2000] put it: “..., membership is becoming more gradual and its meaning increasingly vague".

EU membership does not imply immediate membership in the Economic and Monetary Union (EMU). It is true that for the current crop of accession candidates, any formal derogation from EMU membership, of the kind obtained earlier by the UK and Denmark, will no longer be possible. The obligation to join EMU, once the Maastricht criteria for membership are satisfied, will be part of the 'Acquis Communautaire' that candidate EU members will have to take on board.

However, whether and when the Maastricht criteria are satisfied will be to a significant extent at the discretion of the candidate members. Sweden, for instance, does not have an EMU derogation but has thus far evaded the obligation to join EMU by choosing not to satisfy the exchange rate criterion (successful membership in the Exchange Rate Arrangement (ERM) for a period of at least two years).

The full set of macroeconomic Maastricht criteria for membership in EMU is as follows. There is a pair of financial criteria, a ceiling on the general government deficit-GDP ratio of $3 \%$ and a ceiling on the gross general government debt-GDP ratio of $60 \%$. There also is an interest rate criterion: long-term (ten year) nominal interest rates on the public debt are to be within 2 percent of the average in the three countries with the best inflation record. Next comes the inflation criterion: the annual inflation rate cannot exceed the average of the three best performing countries by more than 1.5 percent. Finally, there is the exchange rate criterion: EMU candidates will (almost surely) have to join an ERM2 arrangement. Within the 15 percent bands, the 
exchange rate will have to be stable (without using capital or exchange controls etc.) for two years prior to joining EMU. There is also the institutional requirement that the central bank be independent. ${ }^{3}$

An important point to keep in mind is that, while the achievement of each of the targets implied by the Maastricht criteria is more or less under the control of the national monetary authority and the national government, the whole set of targets together is not. For instance, the targets on (nominal) interest rates and inflation put constraints on real interest rates; and the target on nominal exchange rates and inflation put restrictions on real exchange rates. Real interest rates cannot be controlled by the national authority, especially not, if there is a high degree of international capital mobility, although they may be able to influence national (default) risk premia. The real exchange rate (the relative price of traded to non-traded goods) is affected by fiscal policy and other structural measures, but also depends on how quickly productivity in the traded and non-traded goods sectors rises to Western European levels. Again this is something the authorities can control only indirectly and imperfectly. Thus, the likelihood and timing of entry will depend on the degree and speed of convergence of the economies of the accession countries with those of the existing EU members. The criteria don't put very severe restrictions on the permissible monetary regime prior to and immediately following accession. Floating within a band or narrow target zone, active exchange rate management, a conventional fixed exchange rate regime, a currency board and full, unilateral euroisation are all consistent with the Maastricht criteria for joining EMU. ${ }^{4}$

Below we investigate the degree to which individual accession countries currently satisfy what we consider to be the two key Maastricht criteria for EMU membership - the inflation and the exchange rate criteria -, and how

\footnotetext{
${ }^{3}$ For more details, see Appendix.

${ }^{4}$ There has been some argument as to whether unilateral adoption of the euro as the sole currency and legal tender by a candidate EMU members is consistent with the criteria. The argument is that, once the domestic currency has been abolished, there no longer is any way for the Council of Ministers to determine the conversion rate at which the candidate EMU member's currency joins EMU. The candidate EMU member would effectively have been able to determine its euro conversion rate unilaterally. Even if the candidate EMU member's own currency is not formally abolished and remained joined legal tender with the euro, the use of the own currency as a means of payment, numéraire and store of value could be discouraged in a variety of ways. The conversion rate ultimately decided by the Council could be irrelevant if the own currency had de facto if not de jure become defunct.
} 
likely and desirable it is that these two criteria can be satisfied in the next five to ten years. ${ }^{5 / 6 / 7}$

${ }^{5}$ The central bank independence criterion does not normally feature prominently in discussions of EMU membership conditionality, but it may turn out to be a binding constraint for at least one leading accession candidate, the Czech Republic, which is currently considering a modification of its central bank statutes which appears likely to violate the Maastricht Criteria. The Maastricht interest rate criterion will be quite difficult to satisfy for a number of accession candidates, because the market for 10 -year government debt is thin or non-existent in quite a few of the accession countries.

${ }^{6}$ We will not consider exchange rate regimes with more than one official exchange rate for current account transactions. We can think of no circumstances under which efficiency, stability or fairness are well-served by a multiple official exchange rate regime for current account transactions. When the same commodity is traded at different prices, there will be distortions, corruption and rent-seeking. Multiple official exchange rate regimes also tend to cause quasi-fiscal deficits for the central bank.

${ }^{7}$ The government debt and deficit criteria have been interpreted so flexibly for the 11 firstround EMU members that joined on January 1, 1999, and for Greece, which become an EMU member on January 1, 2001, that it is hard to conceive of them becoming a binding constraint for future EMU candidates. 


\section{Monetary and Exchange Rate Regimes in Accession Countries: Current Practice}

Before turning to the question as to what the exchange rate arrangements of the accession candidates will be or ought to be, a quick glance at current practices is in order. Table 1 (see next page) characterises the current exchange rate regime of each of the 10 countries and contains a brief description of the current account and capital account restrictions in effect. ${ }^{8}$

Among the 10 Central and East European accession candidates, three have a currency board (Bulgaria and Estonia with respect to the Euro, Lithuania with respect to the US\$), Latvia has a conventional fixed exchange rate regime with a peg against the SDR, Hungary has a crawling peg against a Euro/US\$ basket and the remaining five countries have a managed float. Managed floats cover a wide spectrum of possibilities. There is no suggestion that a managed float is necessarily well-managed. Among the five managed floaters, the Czech Republic has an inflation target net of administered prices, the Slovak Republic has a core inflation target, Poland has a headline inflation target and Slovenia has an M3 growth target. The Romanian central bank (NBR) has price stability as its primary mandate, but does not have an inflation target.

In addition to having differing exchange rate regimes, the 10 accession candidates differ somewhat in their approaches to the international mobility of financial capital. Note, from Table 1, that all of them have adopted IMF Article VIII, which proscribes control on current account transactions. All ten countries have liberalised at least some types of capital account transactions. No country has completely unrestricted mobility of financial capital, although Estonia comes close. Poland has liberalised its controls on long-term capital flows but retains some controls on short-term capital flows, direct investment and real estate transactions.

Motivations for imposing capital controls differ among countries and instruments. So does their effectiveness. Controls on short-term capital flows are often motivated by the desire to avoid sudden large shifts in capital

\footnotetext{
${ }^{8}$ Article VIII of the IMF Articles of Agreement obliges members not to impose controls on current-account transactions.
} 
12 Monetary and Exchange Rate Regimes in Accession Countries: Current Practice

Table 1

\begin{tabular}{|c|c|c|c|c|c|c|c|c|c|c|c|}
\hline 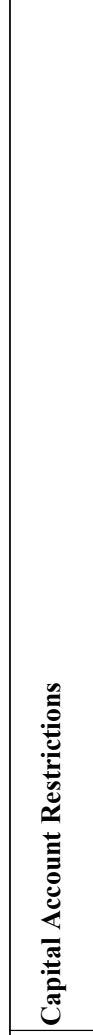 & 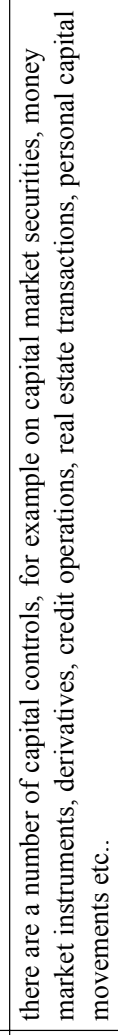 & 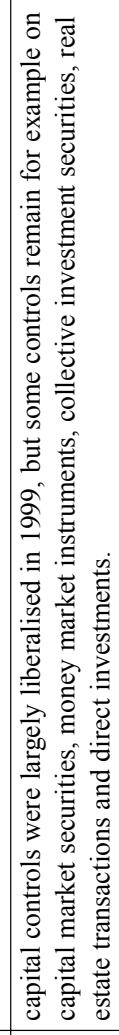 & 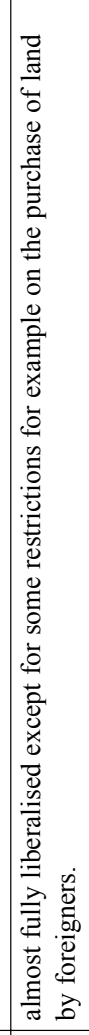 & 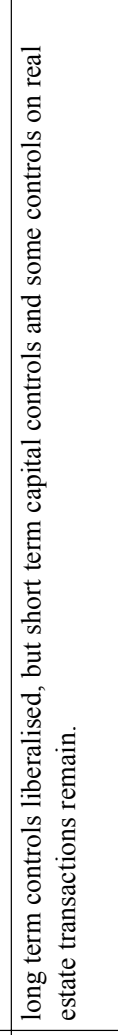 & 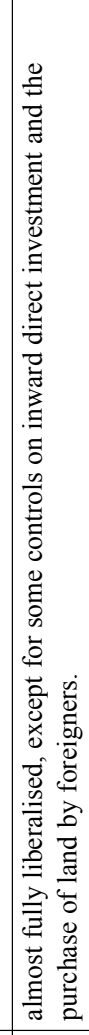 & 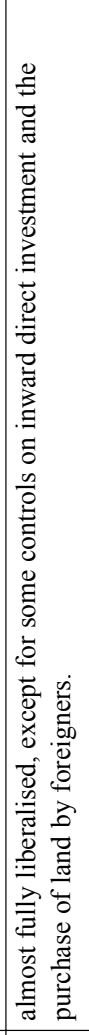 & 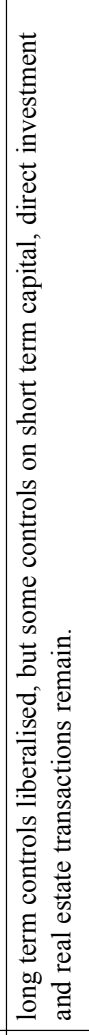 & 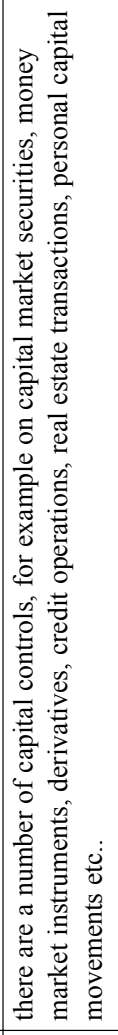 & 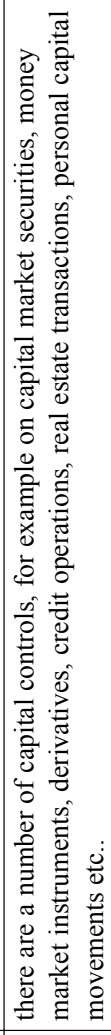 & 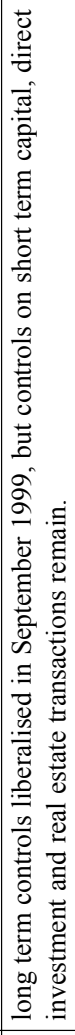 & 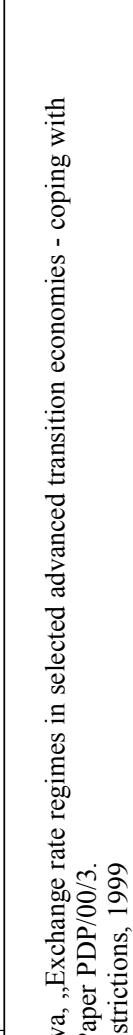 \\
\hline 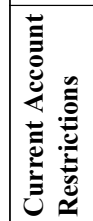 & 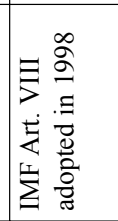 & 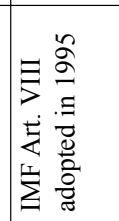 & 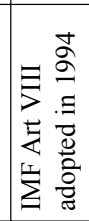 & 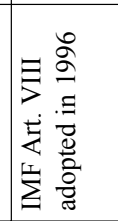 & 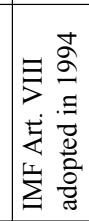 & 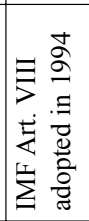 & 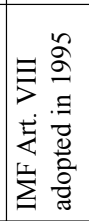 & 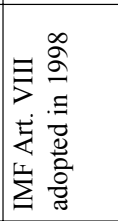 & 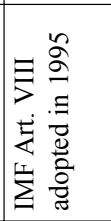 & & \\
\hline \multirow[t]{2}{*}{ 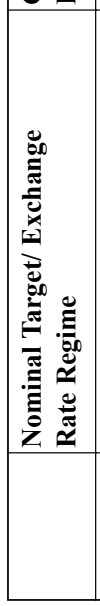 } & 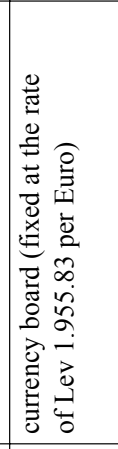 & 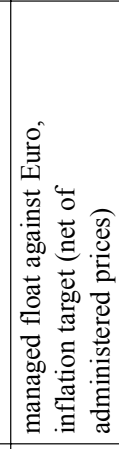 & 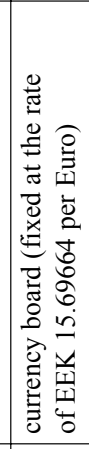 & 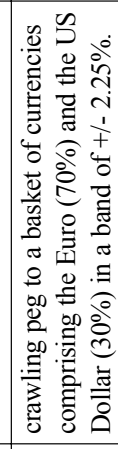 & 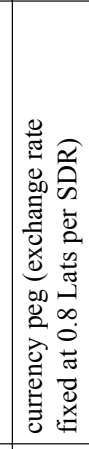 & 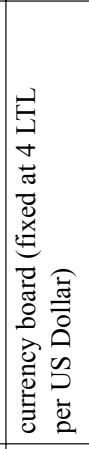 & 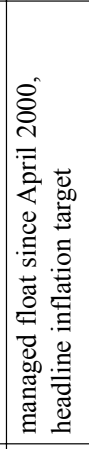 & ్ֶ & 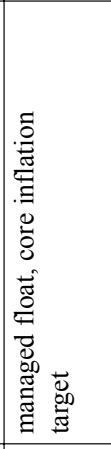 & 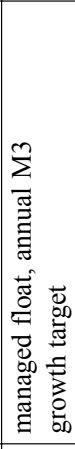 & \\
\hline & 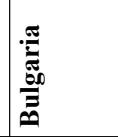 & 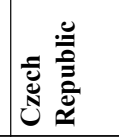 & 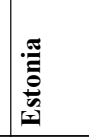 & 䙲 & $\stackrel{\tilde{I}}{3}$ & & & & & & \\
\hline
\end{tabular}


inflows or outflows, which could threaten exchange rate stability and/or undermine the liquidity or solvency of domestic financial institutions. Restrictions on the purchase of land or real estate by foreigners tend to be motivated by non-economic considerations.

The „short term“ in „short-term capital flows“ refers to the remaining time to maturity (or sometimes to the original maturity) of the financial instrument, not to the expected holding period of the investor. If there are liquid secondary markets for long-dated financial instruments, high frequency reversals of capital flows do not require the presence of short-term internationally traded securities. Even FDI is, in principle, easily reversed, if there is a liquid and deep market for ownership claims (equity). Nor does the absence of a large stock of foreign currency liabilities (of any maturity) provide a reason for feeling relaxed about speculative attacks on the currency. What matters here is the capacity or ability to short the domestic currency and go long in foreign exchange in any of a wide range of spot, forward or contingent claims markets.

More generally, the manner in which capital has, in the past, entered a country need bear no relationship to the manner in which capital can, at some later date, leave the country. Take, e.g. a country like Poland, which has recently financed a current account deficit mainly through FDI, including privatisation receipts (that is, the capital account showed net inflows of FDI of a magnitude similar to the current account deficit). There is nothing to prevent such a country from subsequently experiencing a speculative attack against the domestic currency through large scale outflows of short-term or long-term portfolio capital.

While the range of financial instruments that can be traded internationally remains restricted, it is wide enough to expose each one of the 10 accession countries to the threat of sudden, large reversals in capital flows. 



\section{Monetary and Exchange Rate Regimes in Accession Countries: the Optimal Currency Area Perspective}

What is the appropriate exchange rate regime for each of the accession candidates? In what follows we restrict the analysis to the comparison of two exchange rate regimes: a currency board and a floating exchange rate regime with inflation targeting. The experience of these past 20 years seems to support the view that only the two extremes of the currency regime spectrum are viable in a world with few restrictions on the international mobility of capital (see e.g. Fischer [2001]). These two extremes are a credible fixed exchange rate regime and a floating exchange rate. While we will concentrate on these two extreme regimes, we will also, in Section IV, consider the case for making the euro a parallel currency in accession candidates, that is, making it legal tender in all domestic transactions, on the same terms as the local currency.

A common currency or monetary union clearly represents the most credible fixed exchange rate regime. We view monetary union with full membership of EMU as the target regime for the accession countries once EU membership has been achieved. Of course, monetary union with full EMU membership is not an option prior to EU membership, although the unilateral adoption of the EMU as the national currency is.

The next most credible fixed exchange rate regime is a currency board, defined here as a fixed exchange rate regime without domestic credit expansion by the central bank, that is, with $100 \%$ international reserve backing of the monetary base. In the simplest case, foreign exchange reserves are the only financial asset of the monetary authority, with the monetary base the only financial liability. The peg could either involve a single currency or a basket of currencies, as with Latvia's peg to the SDR. For simplicity we consider only a single currency peg vis-à-vis the euro. The euro could, but need not, be legal tender in the country operating the currency board.

Many variations on the pure currency board model have been implemented in practice (see e.g. Ghosh, Gulde and Wolf [2000]). Most involve adding to the asset and/or liability menu of the monetary authority. For instance, domestic commercial banks could have contingent credit lines with the monetary authority; the monetary authority could have contingent credit lines with 
foreign financial institutions, private or public and the monetary authority could have limited authority to extend credit to the government and/or the private sector. Each relaxation of the strict currency board model moves it closer to the traditional central bank managing the oxymoron of a 'fixed-butadjustable' peg.

A floating exchange rate regime is compatible with a number of different nominal anchors, including an index of prices or of inflation rates, or some monetary aggregate. We focus on a regime of inflation targeting, mainly because of its widespread adoption in recent years and the generally favourable experiences under that regime. The definition of the appropriate price index and the specification of the horizon over which the inflation target is to be pursued will be reviewed below.

The following characteristics of an economy have been argued to make nominal exchange rate flexibility desirable.

(1) A high degree of nominal rigidity in domestic prices and/or costs.

(2) A relatively large size and low degree of openness to trade in real goods and services.

(3) A high incidence of asymmetric (nation-specific) shocks rather than symmetric or common shocks and/or dissimilarities in national economic structures or transmission mechanisms that cause even symmetric shocks to have asymmetric consequences.

(4) A less diversified structure of production and demand.

(5) A low degree of real factor mobility (especially labour mobility) across national boundaries.

(6) Absence of significant international (and supra-national) fiscal transfer mechanisms.

\section{Nominal cost and price rigidities}

If there are no significant nominal cost and price rigidities, the exchange rate regime is a matter of supreme macroeconomic insignificance. Note that it is only nominal rigidities that matter. A country can be mired in real rigidities (rigid real wages, inflexible relativities, high non-wage labour costs, stagnating productivity, immobile factors of production) and its real economic performance will be miserable, without this having any implications for the choice of exchange rate regime. Unless these real rigidities can be addressed effectively through nominal exchange rate 
variations, the country's performance will be equally miserable with a credible fixed exchange rate, with a floating exchange rate, or with a system of universal bilateral barter.

The severity and persistence of nominal rigidities therefore becomes a key empirical and policy issue. Unfortunately, the available empirical evidence is extremely opaque and very hard to interpret. Even if information on the duration of nominal wage and price contracts and on the extent to which they are synchronised or staggered is available, its interpretation is obviously subject to the Lucas critique. These contracting practices are not facts of nature, but the outcomes of purposeful choices. Changes in the economic environment conditioning these choices will change the practices.

Testing price and wage data for persistence is equally unlikely to be enlightening. The pattern of serial correlation in the data reflects both 'true' structural lags, invariant under changes in the economic environment, and expectational dynamics that will not be invariant when the rules of the game are perceived to have changed. There is no deep theory of nominal rigidities worth the name.

This leaves us in an uncomfortable position. We believe the numéraire matters, although we cannot explain why (using conventional economic tools). We believe that nominal wage and price rigidities are common and that they matter for real economic performance, but we do not know how to measure these rigidities, nor how stable they are likely to be under the kind of policy regime changes that are under discussion.

\section{Size, openness and direction of trade}

The relevant metric for 'size' in economics is market power. A large country has the ability to influence its external terms of trade (the relative price of exports and imports) or the world prices of the financial securities it deals in (the world rate of interest). From this perspective, even Poland, the largest of the 10 accession countries is small.

A country that is small as regards trade in real goods and services (a price taker in the world markets for imports and exports) cannot use variations in its nominal exchange rate to affect its international terms of trade. Of course, not all final and intermediate goods and services are internationally traded and labour services are overwhelmingly non-traded. Nominal wage rigidities are therefore sufficient to give the nominal exchange rate a (temporary) 
18 Monetary and Exchange Rate Regimes in Accession Countries

handle on the real economy, through its ability to influence relative unit labour costs and profitability.

A common theme in most Optimal Currency Area approaches is that an economy that is more open to trade in goods and services gains less from nominal exchange rate flexibility (see e.g. Mundell [1961], Mc Kinnon [1963]) . It should be obvious that this proposition cannot be correct as stated. For an economy that is completely closed to trade in goods and services, the exchange rate regime is irrelevant, from the point of view of macroeconomic stabilisation. If there is a relationship between degree of openness and the cost of giving up exchange rate flexibility, the relationship cannot be monotone.

Most of the countries in Eastern Europe are much more open to trade today than the late joiners into the EU (Greece, Ireland, Portugal and Spain) were when they joined. The evidence is contained in Table 2 .

Table 2

\begin{tabular}{|c|c|c|c|c|}
\hline \multirow[t]{2}{*}{ Trade (\% of GDP) } & \multicolumn{2}{|c|}{$\begin{array}{c}\% \text { of GDP } \\
\text { (current prices) }\end{array}$} & \multicolumn{2}{|c|}{$\begin{array}{c}\% \text { of GDP } \\
\text { (PPP) }\end{array}$} \\
\hline & 1986 & 1998 & 1986 & 1998 \\
\hline \multicolumn{5}{|l|}{ group of EU late joiners } \\
\hline Greece & 44 & 40 & 15 & 19 \\
\hline Ireland & 103 & 141 & 88 & 134 \\
\hline Portugal & 63 & 72 & 22 & 44 \\
\hline Spain & 38 & 56 & 18 & 37 \\
\hline \multicolumn{5}{|l|}{ group 1} \\
\hline Czech Republic & & 121 & & 44 \\
\hline Estonia & & 169 & & 58 \\
\hline Hungary & & 102 & & 42 \\
\hline Poland & & 56 & & 26 \\
\hline Slovenia & & 115 & & 67 \\
\hline \multicolumn{5}{|l|}{ group 2} \\
\hline Bulgaria & & 91 & & 23 \\
\hline Croatia & & 89 & & 44 \\
\hline Latvia & & 109 & & 37 \\
\hline Lithuania & & 106 & & 40 \\
\hline Romania & & 60 & & 15 \\
\hline Slovak Republic & & 139 & & 46 \\
\hline average late $\mathbf{E U}$ joiner & 62 & 77 & 36 & 59 \\
\hline average group 1 & & 113 & & 48 \\
\hline average group 2 & & 101 & & 32 \\
\hline
\end{tabular}

Source: WDI data base 
While trade accounted for $62 \%$ of GDP on average among the EU late comers, the ratio is almost twice as high for the accession countries of Group 1 and hardly lower for the countries in Group 2. Comparing the two largest economies in Group 1 with most recent EU members, Poland is much more open than Spain was when it joined the EU. Even today Spain's trade does not account for a higher share of GDP than Poland's trade. The picture doesn't change much if we value GDP at PPP rather than at current (market) exchange rates. Poland's trade today still accounts for a higher share of GDP than did Spain's when that country entered the European Union, but Spain's share of trade today is higher than that in Poland. The same is true for the averages in the ratio of Group 1 and the EU late joiners. Furthermore if valued at PPP exchange rates, the share of trade in GDP is higher for the late EU comers when they joined than for the countries in Group 2.

As can be seen from Table 3 below, all accession countries are conducting a large share of their trade with countries in Euroland.

Table 3

\begin{tabular}{|c|c|c|c|}
\hline & $\begin{array}{l}\text { h EU + group } 1 \\
\text { total trade }\end{array}$ & $\begin{array}{l}\text { Trade with EU } \\
\% \text { of total trade }\end{array}$ & $\begin{array}{l}\text { Trade with EMU } \\
\% \text { of total trade }\end{array}$ \\
\hline \multicolumn{4}{|l|}{ group 1} \\
\hline Czech Republic & 75 & 68 & 59 \\
\hline Estonia & 62 & 60 & 39 \\
\hline Hungary & 77 & 73 & 65 \\
\hline Poland & 73 & 67 & 60 \\
\hline Slovenia & 76 & 70 & 64 \\
\hline average & 73 & 68 & 57 \\
\hline \multicolumn{4}{|l|}{ group 2} \\
\hline Bulgaria & & 58 & 38 \\
\hline Croatia & & 54 & 32 \\
\hline Latvia & & 55 & 30 \\
\hline Lithuania & & 43 & 32 \\
\hline Romania & & 72 & 56 \\
\hline Slovak Republic & & 54 & 49 \\
\hline average & & 56 & 40 \\
\hline
\end{tabular}

Source: Direction of Trade Statistics, IMF, June 2000

For the countries in Group 1, this share exceeds 50\% and it rises to more than $70 \%$ if one includes all countries in the European Union and the countries in 
Group 1. Thus, the likelihood of these countries being hit hard by an asymmetric external shock instead of just external shock originating from a country or region outside the EU, is rather small. Even during the turmoil of the Russian and Asian crises, the countries of Group 1, with the exception of Estonia, were not much more affected than the economies of Euroland (see Transition Report 1999).

According to conventional OCA theory, this concentration of trade suggests that the accession countries have a very natural anchor in form of the euro if they chose to go for a currency board. Again, this argument does not appear robust. Presumably a flexible exchange rate vis-à-vis one's main trading partner would be desirable if there were frequent significant real shocks that require an adjustment of international prices, since, in the presence of nominal cost or price rigidities, such an adjustment is more easily achieved through an adjustment of the nominal exchange rate than through variations in domestic and foreign nominal costs and prices at a given nominal exchange rate.

Whatever the merits of the theoretical argument linking exchange rate flexibility and openness, it is clear that by most measures the accession countries are more open than Greece, Ireland, Portugal and Spain were when they joined the European Union. Furthermore most of them conduct a very high share of their trade with one currency block: Euroland.

\section{Asymmetric shocks or transmission}

The 'one-size fits all' monetary policy corset inflicted on the members of a monetary union is most costly if a member state is subject to severe asymmetric shocks or if its structure is such as to cause even symmetric or common shocks to have seriously asymmetric impacts on output and employment. The proposition that a fixed exchange rate is more attractive when the structure of production and demand is well-diversified should be seen as a statement about the conditions under which asymmetric shocks are less likely.

Differences in the structure of production or in the composition of demand may be suggestive of possible asymmetric shocks or asymmetric transmission of common shocks. Table 4 below compares the shares of manufacturing value added and of agricultural value added and employment of the Group 1 countries in 1997 with those of the EU late joiners in 1986. 
Table 4: Sectoral structure of the economies

\begin{tabular}{|c|c|c|c|c|c|c|}
\hline & \multicolumn{2}{|c|}{$\begin{array}{c}\text { manufacturing } \\
\% \text { of value added }\end{array}$} & \multicolumn{2}{|c|}{$\begin{array}{c}\text { agriculture } \\
\% \text { of value added }\end{array}$} & \multicolumn{2}{|c|}{$\begin{array}{c}\text { agriculture } \\
\text { male employment* }\end{array}$} \\
\hline & 1986 & 1995 & 1986 & 1997 & 1990 & 1997 \\
\hline Average EU 85 & 22 & & 4 & $2.4 * *$ & 5.6 & 4.5 \\
\hline Average EU late joiners & 23 & 18 & 9 & $6.1 * *$ & 17.4 & 14 \\
\hline Greece & 15 & 10 & 13 & $11.2 * *$ & 20.5 & 18 \\
\hline Ireland & & & 9 & $6.3 * *$ & 20.7 & 15 \\
\hline Spain & 26 & 18 & 7 & $3.0 * *$ & 12.6 & 10 \\
\hline Portugal & 29 & 25 & 6 & $4.0 * *$ & 15.6 & 12 \\
\hline Average EU 95 & & 19 & & $3.7 * *$ & & 8 \\
\hline Average group 1 & & 23 & & 5 & & 13 \\
\hline Czech Republic & & & & 4 & & 7 \\
\hline Estonia & & 18 & & 7 & & \\
\hline Hungary & & 24 & & 6 & & 11 \\
\hline Poland & & 21 & & 5 & & 21 \\
\hline Slovenia & & 29 & & 4 & & 12 \\
\hline
\end{tabular}

* male employment (\% share of economically active population)

** data is for 1994

Source: WDI data base

While it would be preferable to look at the structure of GDP at a more disaggregated level, at the one digit level the difference between the economies of Group 1 and the current EU do not look any bigger than the difference between the EU late joiners and the EU average (at the time they joined). The two entries that stand out are Poland's share of male agricultural employment in total male employment during 1997, which was $21 \%$, and Poland's share of agricultural value added in total value added in 1997, which was $5 \%$. These two figures imply that the gap between agricultural productivity and economy-wide productivity is very large in Poland, and larger than in the other Group 1 countries.

Identifying and measuring the shocks perturbing the accession countries in the past is an exercise undertaken only by the brave. The further assumption that the patterns revealed in the historical sample would remain valid in the future, pre- and post-accession, is difficult to justify. We limit ourselves to a very simple descriptive statistic. Table 5 below shows how inventory changes in the Group 1 countries have been correlated during the period 1994-1998 with those in France and Germany since 1994. 
22 Monetary and Exchange Rate Regimes in Accession Countries

Table 5: The correlation in annual change of inventories across countries (1994-1998)

\begin{tabular}{|lcc|}
\hline & $\begin{array}{c}\text { Correlation } \\
\text { with France }\end{array}$ & $\begin{array}{c}\text { Correlation } \\
\text { with Germany }\end{array}$ \\
\hline Austria & -0.34 & 0.95 \\
Belgium & 0.72 & -0.77 \\
Denmark & 0.44 & 0.02 \\
Finland & 0.66 & 0.16 \\
France & 1.00 & -0.11 \\
Germany & -0.11 & 1.00 \\
Greece & 0.96 & -0.38 \\
Italy & -0.10 & 0.29 \\
Ireland & 0.62 & 0.71 \\
Luxembourg & 0.67 & 0.28 \\
Netherlands & -0.05 & -0.02 \\
Portugal & 0.68 & -0.03 \\
Spain & 0.45 & -0.88 \\
Sweden & 0.89 & 0.34 \\
United Kingdom & 0.92 & -0.46 \\
\hline average & 0.46 & 0.01 \\
\hline Czech Republic & -0.62 & 0.21 \\
Estonia & -0.45 & 0.84 \\
Hungary & -0.55 & 0.31 \\
Poland & -0.14 & 0.16 \\
Slovenia & 0.87 & 0.28 \\
\hline average & -0.18 & \\
\hline Source: WDI & & 0.25 \\
\hline
\end{tabular}

Source: WDI data base

Statistically, business cycle fluctuations can be 'accounted for' by the inventory cycle. Surprising in Table 5 is the small negative correlation between the Netherlands and Germany, despite the Netherlands being effectively on a DM standard during all of the period. This suggests that there either were few common shocks or that the Dutch economy's response to these shocks, whether through the automatic servomechanisms of the market or through policy, neutralised most of the common shocks. Table 5 also suggests a weaker positive correlation between the German inventory cycle and the inventory cycles of Group 1 than between that of Germany and the other EU countries.

The correlation between, on the one hand, the central bank interest rate set in Frankfurt and, on the other hand, the central bank interest rates in Hungary, 
the Czech Republic, Estonia and Poland between January 1998 and September 2000 is shown in Table 6. It is consistent with the view that over the period in question, only Polish monetary policy followed the lead of first the Bundesbank and then the ECB fairly closely.

Table 6: Correlation of central bank interest rates (January 1998-September 2000)

\begin{tabular}{|cccccc|}
\hline & Hungary & Czech Rep. & Estonia & Poland & UK \\
\hline Euro /Germany & -0.879991526 & -0.457544 & -0.0566075 & 0.872335 & 0.852456 \\
\hline
\end{tabular}

Source: Bloomberg

There are two considerations that qualify the proposition that asymmetric shocks make the retention of nominal exchange rate flexibility desirable. Nominal exchange rate changes are the appropriate response only to asymmetric shocks to the markets for goods and services, that is, to IS shocks and aggregate supply shocks. In response to asymmetric monetary shocks (LM shocks), a constant nominal interest rate is appropriate. In a world with perfect international financial capital mobility, a constant nominal interest rate translates into a constant expected rate of exchange rate depreciation. A credible fixed exchange rate is the simplest way of delivering this optimal response to LM shocks. ${ }^{9}$

Second, it is important not to be excessively impressed with the efficiency of financial markets in general, and with the efficiency of the foreign exchange market in particular. The foreign exchange market and the exchange rate can be a source of extraneous shocks as well as a mechanism for adjusting to fundamental shocks. One cannot have the one without the other. The potential advantages of nominal exchange rate flexibility as an effective adjustment mechanism or shock absorber are bundled with the undoubted disadvantages of excessive noise and unwarranted movements in the exchange rate, inflicting unnecessary real adjustments on the rest of the economy.

\section{Limited real resource mobility}

It is clear that a high degree of real factor mobility can be an effective substitute for nominal exchange rate adjustments in the face of asymmetric

\footnotetext{
${ }^{9}$ This is a straightforward extension of Poole [1970] to an open economy setting with integrated global financial markets (see Buiter [1997]).
} 
shocks. Indeed, factor mobility permits long-term, even permanent, real adjustments to asymmetric real shocks, something nominal exchange flexibility cannot deliver. The real factors whose mobility matters are labour and real or physical capital.

Real capital mobility, both within and between nations, is imperfect or limited, even when financial capital mobility is perfect. Once real capital (plant, machinery and other equipment, infrastructure etc.) is installed, it becomes costly to shift geographically. There are some examples of 'flying capital', such as Jumbo jets, that move very easily and at a low cost, and there have been examples of whole factories being shipped over great distances by rail or by ship. The conventional view in the OCA literature is that, as a first approximation, real capital cannot be relocated. New gross investment can of course be redirected across national boundaries, and financial capital mobility can facilitate this process, by permitting the decoupling of national saving and gross domestic capital formation. This is not a process that is likely to be very significant at cyclical frequencies, however.

The technological developments of the past few decades may make the argument that physical capital, once installed, is very costly to move geographically, progressively less applicable. While a blast furnace is likely to be prohibitively expensive to move geographically, many modern assembly lines for high-tech products are extremely valuable in relation to their weight, bulk, fragility and general unwieldy nature - the proximate determinants of the cost of moving them geographically. They can be, and are, moved over large distances in response to changes in relative costs of production (or to changes in the other determinants of profitability).

There remain many obstacles to labour mobility between the accession countries and the current EU and EMU members. Many obstacles are cultural, including linguistic, or legal and administrative. While throughout the existing EU, work permits are a thing of the past, and mutual recognition of professional qualifications is becoming the norm rather than the exception, cross-border mobility among EU members continues to be limited.

Whatever the cultural, administrative or legal obstacles to labour mobility between the accession countries and the current EU members (in the years prior to accession and in the years following accession), the net migration flows between any two regions or countries are bound to be larger the larger the difference between their real wages or real per capita income levels. Table 7 contains some useful information in that regard. 
Table 7 GNP compared to Euroland both in current $\$$ and in PPP

\begin{tabular}{|c|c|c|c|c|}
\hline & \multicolumn{2}{|c|}{$\begin{array}{c}\text { GNP p.c. as percentage } \\
\text { of EU averages } \\
\text { market prices }\end{array}$} & \multicolumn{2}{|c|}{ PPP } \\
\hline & 1986 & 1997 & 1986 & 1997 \\
\hline \multicolumn{5}{|l|}{ \% of EU 99} \\
\hline Greece & 46 & 55 & & \\
\hline Ireland & 64 & 85 & & \\
\hline Portugal & 31 & 49 & & \\
\hline Spain & 57 & 64 & & \\
\hline average & 49 & 63 & & \\
\hline Czech Republic & & 25 & & 57 \\
\hline Estonia & & 15 & & 35 \\
\hline Hungary & & 21 & & 46 \\
\hline Poland & & 18 & & 35 \\
\hline Slovenia & & 44 & & 67 \\
\hline average & & 25 & & 48 \\
\hline \multicolumn{5}{|l|}{$\%$ of EU 85} \\
\hline Greece & 39 & 48 & 62 & 68 \\
\hline Ireland & 55 & 73 & 48 & 76 \\
\hline Portugal & 27 & 42 & 49 & 62 \\
\hline Spain & 49 & 55 & 62 & 68 \\
\hline average & 42 & 54 & 55 & 69 \\
\hline
\end{tabular}

Source: WDI data base

It shows that, at current market exchange rates, 1998 real per capita income in Group 1 (with the exception of Slovenia) relative to the Euroland average, is half or less what the EU late joiners had relative to the EC average in 1986. This suggests that migration flows from the accession countries to the existing EU members would be significantly larger than those experienced in the late eighties and nineties between the EU late joiners and the earlier members of the EC, especially if the interim or transitional arrangements agreed between the accession countries and the EU significantly relax the current legal and administrative obstacles to migration.

However, Table 7 also shows that at PPP exchange rates, these differences are much smaller. This reflects the fact, discussed at greater length below, that 
GDP comparisons at current exchange rates yield significantly lower relative GDP levels for transition economies than GDP comparisons at PPP exchange rates. This in turn reflects the fact that the relative price of non-traded goods in terms of traded goods is significantly higher in the advanced industrial countries than in transition economies, including the accession countries.

\section{Supranational fiscal stabilisation}

Is a supranational budgetary authority with serious redistributive powers, spanning the existing EMU members and the accession countries necessary to make up for the loss of the exchange rate instrument the accession countries were to adopt a currency board vis-à-vis the euro, or, in due course, were to join EMU? The brief technical answer is 'no'. Fiscal stabilisation policy works if and to the extent that postponing taxes, and borrowing to finance the resulting revenue shortfall, boosts aggregate demand. This will be the case either if there is myopia among consumers, who fail to realise that the present value of current and future taxes need not be affected by the timing of taxes, or if postponing taxes redistributes resources between households with different propensities to consume.

Unless the supranational federal fiscal authority in a currency union has access to the financial markets on terms that are superior to those enjoyed by the national fiscal authorities, there is nothing the federal authorities can achieve by way of fiscal stabilisation that cannot be achieved equally well by national or even lower-tier fiscal authorities. National government financial deficits and surpluses, probably mirrored to some extent in national current account imbalances, are a perfect substitute for supranational fiscal stabilisation.

A study by Bayoumi and Masson [1994], building on earlier work by Sachs and Sala-i-Martin [1992], analyses regional flows of federal taxes and transfers within the USA and Canada. They try to distinguish between long-term fiscal flows (the redistributive element) and short-term responses to regional business cycles, which they identify with the stabilisation element. They find that in the USA, long-run flows amount to 22 cents in the dollar while the stabilisation element is 31 cents in the dollar. For Canada, the corresponding figures are 39 cents and 17 cents respectively. While interesting, these studies tell us nothing of relevance to the issue of whether fiscal policy could compensate for the loss of the exchange rate instrument if an accession country were to give up monetary autonomy. The long-term redistribution properties of the budget are irrelevant, because the nominal 
exchange rate is not an instrument for long-term redistribution. The stabilisation properties of the fiscal system do matter, but the necessary stabilisation can be provided at the supranational, national or sub-national level.

To the extent that monetary union is part of a wider process of political integration, political pressures may grow for long-term redistribution among the nations that constitute the monetary union. What the redistribution figures in the studies of Bayoumi and Masson and of Sachs and Sala-i-Martin tell us, is the degree to which the United States and Canada are societies, rather than just economies, and the extent to which notions of national solidarity and regional social cohesion are translated into redistributive measures through the tax-transfer mechanism. 



\section{Currency Board or Floating-cum-Inflation Targeting: Which one dominates?}

\section{Currency boards}

A currency board is probably the most credible fixed exchange rate regime, although anything that has been made politically can also be unmade politically. A pure currency board has the two key features pointed out in section II: an irrevocably fixed exchange rate and the prohibition of domestic credit expansion by the central bank. The entire monetary base is backed by international reserves. There are several advantages, all of which depend on the currency board arrangement being perceived as credible and permanent.

The first advantage is that the real resource cost of a currency board is less than that of a full fledged, traditional monetary authority. Of course, banking supervision and regulation are still required, but these activities need not be undertaken by the monetary authority.

The second 'advantage' is that a nation adopting a pure currency board throws away the key to the drawer labelled 'monetary financing of government budget deficits'. In a well-run economy, with a benevolent, competent and credible policy maker, this would actually be a drawback (see Calvo et al. [1992]). Seigniorage can be a useful source of revenue for cash-strapped governments. There is no reason to believe that the inflation rate generated under a currency board is anywhere near the optimal rate from a neoclassical public finance point of view.

However, political economy considerations, distilled from the often brutal lessons of history, suggest that the printing press is a great seducer, and that the freedom to issue monetary liabilities at will is likely to be abused. Of course, responsible domestic credit expansion by the monetary authority is not achievable only through the medium of a currency board. ${ }^{10}$ Any independent central bank (whether instinctively conservative and with both operational and target independence, or with just operational independence, but dedicated to an externally imposed mandate of price stability), could, in principle, prevent the abuse of the printing presses. This, however, begs a

\footnotetext{
${ }^{10}$ If such were the case, the world as a whole would not be able to implement responsible domestic credit expansion policies.
} 
30 Currency Board or Floating-cum-Inflation Targeting: which one dominates?

number of key questions. Can the political realities support an operationally and target-independent central bank? Would price stability be the overriding target of a target-independent central bank? How would an operationally central bank internalise an externally imposed price stability mandate? And who would impose such a mandate on the central bank?

In many transition countries, the central bank is not even nominally independent. Where it is nominally independent, it is often not effectively independent. This problem is compounded by the fact that the central bank in a number of transition economies does not limit itself to conventional central banking roles (monetary policy and supervision and regulation of the banking and financial systems), but also acts as a development bank and performs commercial roles.

Among the traditional functions of a central bank is that of a lender of last resort, to avoid liquidity crunches, including bank runs in times of financial crisis. Under such circumstances the central bank should lend freely, against the best available collateral, and at punitive rates. If a liquidity crisis becomes a solvency crisis, the central bank does not have the resources to act effectively. Only the state, through the Treasury and its power to tax, has the resources to recapitalise insolvent financial institutions.

One obvious drawback of a currency board is that there can be no lender of last resort, since domestic credit expansion by the monetary authority is ruled out (see Chang et al. [1998], della Paolera et al. [1999]). There may be ways of partially privatising the lender of last resort function by arranging contingent credit lines, but the scope for that is inevitably limited.

A currency board makes the most sense for small, highly open countries. If a country opts for a currency board, it should peg to a currency or to a basket of currencies that accounts for the lion's share of its external trade. For all accession countries, the euro (or a currency basket with a dominant euro share), will be the natural choice. Pegging to the US dollar or even to the $\mathrm{SDR}$, is an open invitation for trouble.

\section{The experience with existing currency boards}

As mentioned earlier, it has often been argued that currency boards (like all (credible) fixed exchange rate regimes) involve a significant cost in terms of foregone real growth in the long run, because the central bank is not able to stabilise output after asymmetric shocks. A recent paper by Ghosh et al. 
[2000] discredits this claim to some extent by investigating systematically the growth performance of countries that have operated currency boards. When controlling for the usual factors thought to determine growth, they actually find, instead of a lower growth performance, a higher growth performance. The obvious criticism to this sort of approach is that there might be what econometricians call a selection bias in the sample on which the study is based. Countries that introduce currency boards might very well have "good“ governments, while the quality of governments across the rest might be much more mixed.

Across transition countries, there is also very little evidence so far that currency stability in countries with currency boards has been bought at the cost of real output stability or growth. Even though Bulgaria and some of the Baltics have struggled following the Russian and Kosovo crises, it could be argued that the non-currency board counterfactual could have been even worse.

\section{Inflation targeting}

Inflation targeting has been 'en vogue' in most industrialised countries for quite some time. Although the US Fed is not quite doing it formally, its actual operating procedures under Volcker and Greenspan mimic inflation targeting. The Bank of England has been doing it since 1992 and the ECB since 1999 (albeit without admitting to it). New Zealand, Australia and Canada also use inflation targeting. So, why not the accession candidates?

Although there are quite a few differences among the above-mentioned monetary authorities in how inflation targeting is actually designed and implemented, there is a common core of key requirements for effective inflation targeting found in all three. This goes well beyond the government announcing some short term inflation target. This common core consists of the following:

1. the public announcement of a numerical medium-term target for inflation for a clearly defined basket of goods and services, ${ }^{11 / 12}$

2. an institutional commitment to price stability as the primary goal of monetary policy, to which other goals are subordinated,

\footnotetext{
${ }^{11}$ This can be a point target, a range or a ceiling.

12 The US Fed does not announce a numerical inflation target. Its official targets are maximum employment, price stability and interest rate stability.
} 
32 Currency Board or Floating-cum-Inflation Targeting: which one dominates?

3. a credible toolbox for linking monetary instruments to medium term inflation outcomes, that makes use of all the information available,

4. transparency of the monetary policy strategy through communication with the public.

Inflation targeting is said to have the key advantage that a country can keep control over its monetary policy, which is in principle desirable in the presence of asymmetric shocks. Nevertheless, in many countries it has proven quite difficult to exploit this advantage. Monetary independence permits flexibility (the valuable ability to respond to shocks), but the downside of flexibility is opportunism, that is, discretion in the negative sense of lack of credible precommitment. Independence associated with opportunistic discretion has been discredited by the inflationary experience of the 70's, and 'rules based' monetary policy, that is, monetary policy based on credible precommitment, is the height of fashion among main stream economists. Of course, rules can, in principle, be flexible, contingent rules that permit a response to news. Unfortunately, it turns out to be rather complicated to write down the optimal rule (flexible, but with commitment). Thus, for example, in the case of New Zealand, one of the front runners in rules-based monetary policy, there is now a wide-spread sense that the central bank did not have enough positive discretion, that is, flexibility, in the wake of the Asian Crisis.

Furthermore, the benefits of monetary independence in most accession countries should not be overstated. Monetary policy is unlikely to be very effective in stabilising output because credit, deposit and debt markets are still rather underdeveloped. Furthermore, especially in the less advanced countries, a substantial share of credits and deposits continues to be in foreign currency. Thus, changes in the cost and availability of domestic credit are unlikely to have a large immediate effect on output, either through the interest rate or through the credit channel.

Accepting inflation as the overriding goal of monetary policy and giving up the goal of stabilising the exchange rate can have important repercussions for the banking system. Especially in the less advanced countries of the region, large parts of the balance sheets of banks are still in dollars and other hard currencies. Even if the balance sheet of the bank itself is balanced as regards its foreign currency liabilities and assets, this need not be adequate insurance against loss in case of large fluctuations in the exchange rate. A large depreciation may lead to defaults by parties that have borrowed from the bank in hard currency without matching the currency denominations of their own 
debits and credits. Such borrower defaults can have a knock on effect on the banking system.

A further important requirement for inflation targeting is the institutional commitment of the central bank to the aim of price stability. This involves the insulation of the policymaking board of the central bank from the partisan political process. Members of the policy-making board of the central bank should not have close ties to political parties or factions. They should be appointed for a single term of office, which should be longer than the political cycle.

Much of the success of the inflation targeting central banks depends on hardgained reputation. Both the Bundesbank for much of its existence and the current chairman of the Fed had or have an almost god-like status in the public eye. Thus, they were or are very well insulated from short term political pressures. No government or even academic in Germany blamed slowdowns in the economy on the Bundesbank.

While reputations take time to establish, the experience of the Bank of England has shown that it is possible to gain the trust of the financial markets without having to painstakingly build a reputation over a long period of time. A crucial element in gaining a reputation quickly is transparency and active engagement in explaining policy decisions to the public. The Bank of England, which gained operational independence only in June 1997, reaches out even further by publishing within a fortnight of its monthly rate-setting meetings, the minutes of these meetings and the votes of the individual members of its policy-making Monetary Policy Committee. It also publishes its quarterly Inflation Report, summarising its view on the performance of past and future monetary policy and the prospects for inflation. Some authors go as far as arguing that the communication of its strategy to the public has been central to the success of inflation targeting in industrialised countries in recent years. In the same vein, the less than wholly satisfactory performance of the ECB since January 1999 has been attributed by some to its lack of openness, transparency and accountability, both as regards its objectives and as regards its operating procedures.

\section{The optimal inflation target}

Over the recent years a lot of research has gone into the question of what constituted the optimal inflation target. This involves the composition of the target basket, the horizon over which the target is to be pursued and the numerical value assigned to the target. Currently the Czech central bank 
targets net inflation (inflation stripped of administrative prices and the effect of tax changes) $)^{13}$ for up to 30 months ahead. The Polish Central bank instead targets headline inflation for at most 18 months ahead.

The consensus for very open economies appears to be that ideally the central bank should target a medium term inflation target that filters out temporary variations in the inflation rate, such as those due to transitory exchange rate movements. The advantage of this approach over simple consumer price basket targeting are higher the more open the economy is and the more volatile the exchange rate. Paying attention to these issues is the more important the larger and more volatile capital flows are. Especially when domestic financial markets and the foreign exchange market lack depth and breadth, capital flows can easily have large transitory effects on the exchange rate.

The challenges posed by international financial integration will continue to be important for the accession countries, and on balance, its effects are likely to be beneficial, provided effective regulation and supervision of domestic financial institutions and markets can be established. With rapidly ageing populations, domestic saving rates are unlikely to be sufficient to finance the capital stock replacement and expansion necessary to catch up with the EU (see Transition Report 2000). FDI inflows are key to the international transfer of technology and know-how. International portfolio diversification offers insurance possibilities that are not available domestically.

The downside of international financial integration is that the international financial market system can be a source of volatility, shocks and instability. Exchange rate volatility is reflected in import price volatility and temporary variations in the rate of inflation. This effect is stronger the more open the economy is to trade in goods and services. Undue sensitivity of domestic monetary policy to such short-term movements in the inflation rate can be destabilising for the real economy. Skilful monetary targeting filters out the noise in the observed price, exchange rate and inflation signals and extracts signal concerning the underlying inflation rate. It is sometimes argued that if highly open transition economies target inflation, they should target 'domestically generated inflation'. Unfortunately, there is no conceptually clean way of separating imported and domestically generated inflation.

\footnotetext{
${ }^{13}$ Note that this is easier said than done. Simply stripping administered prices out of the price index is likely to be a nonsense. The behaviour of the non-administered price component is most unlikely to be independent of the behaviour of the administered prices. For instance, freezing administered prices in an inflationary environment is likely to increase the inflation rate of the non-administered prices.
} 


\section{Balassa-Samuelson meets the EMU Inflation and Exchange Rate Criteria}

There may be a conflict between a key structural feature of the accession countries and the inflation and exchange rate criteria for EMU membership. We will show that, unless the inflation criterion is relaxed or reinterpreted for accession countries adopting a currency board (or any other credible fixed exchange rate regime), EMU may only be achievable at the expense of an unnecessary recession in the accession countries.

Likewise, for those candidate EMU members that adopt a floating exchange rate, it is likely to be necessary for the exchange rate stability criterion to be interpreted asymmetrically if the inflation criterion is to be satisfied. That is, unlike significant exchange rate depreciations, significant exchange rate appreciations should be permitted during the two year "probationary period.

Together, the exchange rate criterion and the inflation criterion restrict the scope for changes in the real exchange rate of the accession candidate vis-à-vis Euroland. To have, say, a real appreciation requires either a nominal appreciation (holding accession country and Euroland inflation rates constant), or a higher domestic rate of inflation relative to Euroland (holding the nominal exchange rate constant).

Real exchange rates of transition economies are volatile and subject to large medium-term swings. There can be little doubt, however, that for most accession countries, there must be the expectation, as part of the process of transition and catch-up, of a significant trend appreciation of the real exchange rate. The reason for this belief is the Balassa-Samuelson effect (see Balassa [1964], Samuelson [1964, 1994], Heston, Nuxoll and Summers [1994]).

Let $\pi_{A}^{T}$ denote the inflation rate of traded goods prices in the accession country, $\pi_{T}^{E}$ the inflation rate of traded goods prices in Euroland and $\varepsilon$ the proportional rate of depreciation of the accession country's currency vis-à-vis the Euro. Assume that the law of one price holds for traded goods, that is, the forces of international trade arbitrage equalise the prices of traded goods and services (expressed in a common currency) between Euroland and the accession candidate. Then 


$$
\pi_{A}^{T}=\pi_{T}^{E}+\varepsilon
$$

The inflation rate relevant for the inflation criterion for EMU membership is the inflation rate of a broad-based consumer price index, which includes both traded and non-traded goods. Let $\pi^{A}$ and $\pi_{N}^{A}$ be the CPI inflation rate, respectively the non-traded goods inflation rate, in the accession country and $\pi^{E}$ and $\pi_{N}^{E}$ the CPI inflation rate, respectively the non-traded goods inflation rate, in Euroland. The share of non-traded goods in the consumption bundle is $\alpha$ both in the accession country and in Euroland. It follows that

$$
\pi^{i}=\alpha \pi_{N}^{i}+(1-\alpha) \pi_{T}^{i} \quad i=A, E
$$

The price of (non-)traded goods is a mark-up on unit labour costs. Assume the growth rate of wages within a country is the same for both sectors and that the proportional mark-up on unit labour costs is constant. The growth rate of money wages in country $i$ is $w^{i}$ and the sectoral productivity growth rates are denoted $g_{N}^{i}$ and $g_{T}^{i}, i=A, E$. It follows that

$$
\pi^{A}=\pi^{E}=\varepsilon+\alpha\left[\left(g_{T}^{A}-g_{N}^{A}\right)-\left(g_{T}^{E}-g_{N}^{E}\right)\right]
$$

Thus, under reasonable assumptions, the difference between the CPI rates of inflation in an accession country and Euroland equals the proportional rate of deprecation of the nominal exchange rate plus the (common) share of nontraded goods in the consumption basket, multiplied by the excess of the productivity growth differential between the traded and non-traded goods sectors in the accession country over that same sectoral productivity growth differential in Euroland. It seems likely that the differential between productivity growth in the traded goods sector and productivity growth in the non-traded goods sector is larger in the candidate accession country than in Euroland, because productivity catch-up is likely to be faster in the traded goods sector than in the sheltered sector. This means that the relative price of non-traded goods to traded goods will be rising faster in the accession candidate than in Euroland. This in turn implies that, at a given exchange rate, the overall inflation rate will be higher in the accession candidate than in Euroland.

Table 7 is consistent with this presentation. It shows, first, that there is a sizeable gap in real per capita income, and therefore also in aggregate labour productivity, between the accession countries and the existing Euroland 
members. Aggregate productivity catch-up is therefore possible and, in our view, likely. Second, the real per capita GDP gap is much larger at market exchange rates than at PPP exchange rates. Group 1 average real per capita income is $21 \%$ of the Euroland level at market exchange rates and $48 \%$ at PPP exchange rates. This reflects the fact that the relative price of non-traded goods to traded goods is much lower in the accession countries than in Euroland, reflecting a larger differential between the traded sector productivity levels of Euroland and the accession countries than between the non-traded sector productivity levels. If there is gradual catch-up between the accession countries and Euroland on a sector-by-sector bases, the relative price of non-traded goods will rise in the accession countries, since their productivity growth differential between the traded goods sector and the nontraded sectors can be expected to be larger than the corresponding Euroland productivity growth differential.

If, at full capacity utilisation and a fixed exchange rate, the inflation differential were to exceed the 1.5 percent permitted by the Maastricht inflation criterion, the only way the candidate EMU member could meet the inflation criterion at a fixed exchange rate would be to have a transitional recession to depress the inflation rate for at least one year to the level required by the Maastricht treaty. Following EMU membership however, the inflation rate in the former accession country would continue to exceed that of the older EMU members by the margin implied by the Balassa-Samuelson effect, for as long as these intersectoral productivity growth differentials have not converged.

A more elegant solution, permitting the EMU candidate to maintain a fixed exchange rate without incurring an unnecessary recession would be to redefine the inflation criterion of the Maastricht treaty in terms of the inflation rate of traded goods only.

Establishing a currency board when the domestic rate of inflation is well in excess of what can be rationalised with reference to the Balassa-Samuelson effect would lead to a period of declining price and cost competitiveness because of inertia or stickiness in the domestic wage-price process. Bringing down inflation to the level warranted, at a fixed exchange rate, by the BalassaSamuelson effect and recouping the initial loss of competitiveness would require a period of excess capacity. Inflation rates still differ markedly among the accession countries, as is evident from Table 8 . 
38 Balassa-Samuelson meets the EMU Inflation and Exchange Rate Criteria

Table 8 Inflation Rates

\begin{tabular}{|c|c|c|}
\hline & 1986 & 1999 \\
\hline \multicolumn{3}{|l|}{ Group 1} \\
\hline Czech Republic & & 2.1 \\
\hline Estonia & & 3.3 \\
\hline Hungary & & 10.1 \\
\hline Poland & & 7.3 \\
\hline Slovenia & & 6.1 \\
\hline average & & 5.8 \\
\hline \multicolumn{3}{|l|}{ Group 2} \\
\hline Bulgaria & & 0.7 \\
\hline Croatia & & 4.2 \\
\hline Latvia & & 2.4 \\
\hline Lithuania & & 0.8 \\
\hline Romania & & 45.8 \\
\hline average & & 10.8 \\
\hline \multicolumn{3}{|l|}{ EU late joiners } \\
\hline Greece & 23.0 & \\
\hline Ireland & 3.8 & \\
\hline Portugal & 11.7 & \\
\hline Spain & 8.8 & \\
\hline average & 11.8 & \\
\hline EU average & 2.4 & 1.1 \\
\hline
\end{tabular}

Source: WDI data base; ECB Monthly Bulletins

In Group 1, the lowest inflation rate in 1999 was achieved by the Czech Republic, with $2.1 \%$. Hungary had the highest inflation rate with $10.1 \%$, followed by Poland with 7.3\%. Poland's inflation rate for 2000 is likely to come out at around $10 \%$, as is Hungary's.

Note that even if a candidate EMU member subject to the Balassa-Samuelson effect were to float its exchange rate there might be problems in satisfying the Maastricht criteria. Consider the case where monetary policy in the accession country were to keep inflation at a level no more than $1.5 \%$ above the Euroland level, but the inflation differential warranted by the BalassaSamuelson effect is greater than $1.5 \%$ at a given exchange rate and at full capacity. The equilibrium response of the exchange rate would be an appreciation. This could cause the accession country to fall foul of the exchange rate criterion, depending on how this is interpreted. The Balassa- 
Samuelson effect is unlikely to exhaust the $15 \%$ bands of the ERM in two years, assuming the exchange rate starts off in the middle of the band, but the treaties are unclear as to whether merely staying within the $15 \%$ bands is sufficient for satisfying the exchange rate criterion for EMU membership. One way out of this problem would be to interpret the exchange rate criterion asymmetrically, that is, to accept revaluations but not devaluations. ${ }^{14}$

Until the transition candidate has evolved, structurally, to the point that there no longer is any need for a steady appreciation of its real exchange rate, it may be difficult to meet both the inflation and the exchange rate criteria for EMU membership. Two ways out of this dilemma are (1) to re-interpret the inflation criterion to apply only to the inflation rate of traded goods and (2) to interpret the exchange rate stability criterion asymmetrically, permitting nominal exchange rate appreciation during the two year period preceding EMU membership.

\footnotetext{
${ }^{14}$ The Treaty does indeed not explicitly rule out revaluations or appreciations of the exchange rate. Only devaluation is explicitly considered inconsistent with EMU membership.
} 



\section{The Euro as Parallel Currency for Accession Countries}

One way for an accession country to give visible expression to its desire for eventual EMU membership, is to make the euro a parallel currency for the country in question. The euro would be declared legal tender for all transactions under the accession country's jurisdiction, on the same terms as the local currency. Residents would be able to operate checkable euro accounts with local financial institutions. The introduction of the euro as a parallel currency, that is, as a competing currency with legal tender status circulating alongside the fully convertible local currency would provide additional monetary discipline. Local narrow money and the euro would become closer direct substitutes. By making the euro a better direct substitute for the local currency, any attempt at inflationary financing would be reigned in by a shift in money demand away from the local currency and towards the euro. In the limit, any non-zero anticipated depreciation of the local currency against the euro would drive the demand for the local currency to zero; likewise, any non-zero anticipated appreciation of the local currency against the euro would reduce the local demand for euros for domestic transaction purposes down to zero - a pure Kareken and Wallace world (Kareken and Wallace [1981]). ${ }^{15}$ Even under less idealized circumstances, the sensitivity of the demand for local base money to expected depreciation/appreciation of the exchange rate would be certain to increase if the euro were made legal tender.

A variety of monetary and exchange rate regimes are consistent with such enhanced direct currency competition. At one extreme are the unilateral adoption of the euro as the only legal tender, and the abolition of the domestic currency. A currency board is consistent with the euro as parallel currency, but so are managed and floating exchange rate regimes. Of course, if the euro and the local currency were to become perfect direct substitutes, even a floating exchange rate regime would turn out to support only constant exchange rate equilibria. Any expected depreciation or appreciation would imply the total abandonment of the currency that is expected to weaken.

\footnotetext{
${ }^{15}$ Narrow or base money is assumed to be non-interest bearing. The Kareken and Wallace universe has the further interesting property that the level of the (expected) equilibrium exchange rate, while constant, is indeterminate. Nominal price and/or wage rigidities would eliminate this indeterminacy, but not the requirement that the expected equilibrium exchange rate be constant.
} 
There is some historical experience with parallel currencies, and with the behaviour of the inflation rates for the two currencies and the exchange rate between them. A parallel or bi-currency standard has been used successfully as a transitional mechanism to achieve monetary stability by Brazil in 1994 under the so-called „Real Plan“. Brazil adopted a new currency, the real, pegged and fully backed by the US \$. This real circulated alongside the old currency, the cruceiro, which was Brazilian fiat money unbacked by US dollars. After a few months, economic agents shifted, of their own volition, towards using the new currency for invoicing and contracting. They also increasingly abandoned the old currency as a transactions medium. The result was a speedy reduction in the real value of the old currency and its de facto (and later also de jure) abolition. Later on, of course, the link of the real and the US dollar was abandoned, and the real turned out to be a nominal after all.

Parallel currencies have a much longer history, however, and can be found in eastern Europe during extraordinary times. In 1921, the Soviet government, as part of the so-called New Economic Policy, created a new currency, the chervonets, backed by gold. For two years, this currency circulated alongside the rouble (the called sovznak). Prices stabilised in the new currency immediately, but inflation and devaluation continued in the old currency along with monetary deficit financing (using the old currency). When the budget was balanced in 1924, the old currency had been effectively repudiated through hyperinflation and all contracts had become denominated in chervonets at stable prices (Cagan [1956], Rostowski and Shapiro [1992], Fischer [1994]). One can view this as a real-time approximation to a KarekenWallace equilibrium. 


\section{Conclusion: Is Inflation Targeting a Better Option for Accession Countries Than a Currency Board?}

The criteria for accession to Economic and Monetary Union in their current form include a ceiling for the permissible rate of inflation one year prior to accession, in the price of a basket of consumer goods defined by Eurostat. An exchange rate stability objective or constraint is also imposed for a 2-year period prior to accession. The normal (presumably 15\%) fluctuation margins must be satisfied and there can be no devaluations.

It is clear that these criteria do not provide a perfect fit for either a currency board or inflation targeting. Because of the Balassa-Samuelson effect, a currency board arrangement may well fail to produce an inflation rate below the Maastricht ceiling, unless the economy is run with a wasteful amount of spare capacity.

Pure inflation targeting is consistent both with a highly volatile exchange rate and with persistent, medium-term misalignments. The credibility of any inflation target would be undermined by the requirement that the exchange rate be kept within a specified target zone. In addition, the inflation criterion of the Maastricht treaty is a 'raw' consumer price index, with no allowance for difference between actual and 'core' inflation or between transitory and permanent changes in the inflation rate.

It seems unlikely that a currency board arrangement will be able to deliver satisfaction of the inflation criterion for EMU membership without an unnecessary recession. The sensible alternative, a respecification of the inflation ceiling in terms of traded goods price inflation (and preferable in terms of 'core' traded goods price inflation), would require a change in the Treaty.

Inflation targeting can, unless the exchange rate becomes very volatile, deliver the inflation and exchange rate stability conditions for EMU membership if the exchange rate criterion is interpreted asymmetrically, and permits appreciations or revaluations of the exchange rate.

Introducing the euro as a parallel currency in transition countries deserves serious consideration. Such an act does not prejudge the details of the monetary and exchange rate regime. It could be viewed as a means of 
signalling a desire for eventual euroisation, through full EMU membership, without the need for an immediate abandonment of the local currency through unilateral euroisation. 


\section{References}

Balassa, B. [1964], „The Purchasing Power Parity Doctrine: A Reappraisal“, Journal of Political Economy, December.

Bayoumi, Tamin and Paul R. Masson [1994], „Fiscal flows in the United States and Canada: Lessons for monetary union in Europe." Discussion Paper 1057, Centre for Economic Policy Research (November).

Beaumont, Craig, Robert Corker, Rachel van Elkan and Dora Iakova [2000], „Exchange Rate Regimes in Selected Advanced Transition Economies-Coping with Transition, Capital Inflows, and EU Accession.“ IMF Policy Discussion Paper PDP/00/3.

Berglof, Eric and Gerard Roland [2000], „From Regatta to 'Big Bang' - The Impact of the EU Accession Strategy on Reforms in Central and Eastern Europe“, IMF Working Paper, August.

Buiter, Willem [1997], „The economic case for monetary union in the European Union.“ in C.Deissenberg, R.F. Owen and D. Ulph eds. European Economic Integration, supplement to the Review of International Economics, 5(4): pp. 0-35.

Buiter, Willem H. and Anne S. Sibert [2000], „Targets, Instruments and Institutional Arrangements for an Effective Monetary Authority“, Seventh L.K. Jha Memorial Lecture, October, Reserve Bank of India.

Cagan, Phillip [1956], „The monetary dynamics of hyperinflation“, in Milton Friedman ed. Studies in the Quantity Theory of Money, Chicago, the University of Chicago Press.

Calvo, Guillermo A. and Leonardo Leidermann [1992], „Optimal inflation tax under precommitment: Theory and evidence.“ American Economic Review (March): 179-94.

Chang, Roberto and Andres Velasco [1998], „Financial fragility and the exchange rate regime. “ NBER Working Paper 6469 (March).

Christofferson, Peter F. and R.F.Wescott [1999], „Is Poland Ready for Inflation Targeting?" IMF Working Paper WP/99/41.

Della Paolera, Gerardo and Alan Taylor [1999], „Internal versus external convertibility and developing country financial crisis: Lessons from the Argentinean bank bail out of the 1930's.“ NBER Working Paper 7386 (October).

Fischer, Stanley [1994],,Russia and the Soviet Union Then and Now“, in O.J. Blanchard, K.A. Froot and J.D. Sachs eds. The Transition in Eastern Europe, Vol. 1. Country Studies, pp. 221-252. NBER, The University of Chicago Press, Chicago and London.

Fischer, Stanley [2001], Exchange Rate Regimes: Is the Bipolar View Correct?,,, Mimeo, IMF, January.

Frankel, Jeffrey A. [1999], „No single currency regime is right for all countries or at all times.“ NBER Working Paper 7338 (September).

Ghosh, Atish R., Anne-Marie Gulde and Holger C. Wolf [2000], „Currency boards: more than a quick fix“, Economic Policy, 31, October 2000, pp. 271-335. 
Gulde, Anne-Marie, Juha Kähkönen and Peter Keller [2000], „Pros and Cons of Currency Board Arrangements in the Lead-up to EU Accession and Participation in the Euro Zone“, IMF Policy Discussion Paper, PDP/00/1, January.

Heston, Alan, Daniel A. Nuxoll and Robert Summers [1994], „The DifferentialProductivity Hypothesis and Purchasing-Power Parities: Some New Evidence“, Review of International Economics; 2(3), October, pages 227-43.

Kareken, John and Neil Wallace [1981], „The indeterminacy of equilibrium exchange rates“, Quarterly Journal of Economics, 96, May, pp. 207-22.

Masson, Paul R. [1999], „Monetary and exchange rate policy of transition economies of Central and Eastern Europe after the launch of EMU.“ IMF Policy Discussion Paper $\mathrm{PDP} / 99 / 5$.

McKinnon, Ronald I. [1963], „, Optimum currency areas.“ American Economic Review 53 (September): 717-25.

Mishkin, Frederic S. [2000], „Inflation targeting in emerging market countries.“ NBER Working Paper 7618.

Morales, Arnando R. [2000], „Czech Koruna and Polish Zlothy currency options: information content and EU-accession implications." IMF Working Paper WP/00/91.

Mundell, Robert A. [1961], „A theory of optimum currency areas.“ American Economic Review 51 (September): 657-65.

Poole [1970], „Optimal Choice of Monetary Policy Instruments in a Simple Stochastic Macromodel“", Quarterly Journal of Economics, 84, pp. 197-216.

Rostowski, Jacek and Judith Shapiro [1992], „Secondary Currencies in the Russian Hyperinflation and Stabilisation of 1921-1924“, LSE Centre for Economic Performance Discussion Paper No 59.

Roubini, Nouriel [1998], „The case against currency boards: debunking 10 myths about the benefits of currency boards." NYU Stern mimeo.

Sachs, Jeffrey D. and Xavier Sala-i-Martin [1992], „Fiscal federalism and optimum currency areas.“ In Matthew B. Canzoneri, Vittorio U. Grilli and Paul R. Masson, eds., Establishing a central bank: Issues in Europe and lessons from the U.S. Cambridge, UK: Cambridge University Press.

Samuelson, Paul A. [1964], „Theoretical Notes On Trade Problems“, Review of Economics and Statistics, May.

Samuelson, Paul A. [1994], „Facets of Balassa-Samuelson Thirty Years Later“, Review of International Economics; 2(3), October, pages 201-26.

Transition Report [2000], European Bank for Reconstruction and Development, London, UK. 


\section{Appendix: Criteria for the Accession to EU and EMU}

\section{Criteria for accession into the $\mathbf{E U}$ :}

In 1993, at the Copenhagen European Council, the Member States took a decisive step towards enlargement, agreeing that 'the associated countries in central and eastern Europe that so desire shall become members of the European Union.' The declaration went on to define criteria that need to be fulfilled by the countries before they can enter, often referred to as the Copenhagen Criteria.

As stated in Copenhagen, membership requires that the candidate country

has achieved: stability of institutions guaranteeing democracy, the rule of law, human rights and respect for and protection of minorities; the existence of a functioning market economy as well as the capacity to cope with competitive pressure and market forces within the Union; the ability to take on the obligations of membership including adherence to the aims of political, economic and monetary union.

has created: the conditions for its integration through the adjustment of its administrative structures, so that European Community legislation transposed into national legislation is implemented effectively through appropriate administrative and judicial structures.

Thus the only condition in these criteria that address the question of monetary regimes is that any entrant into the EU will also make every effort to join the European Monetary Union in the medium term. None will be able to negotiate an opt out like Great Britain.

\section{Criteria for accession into EMU}

The criteria for the accession into the Monetary Union are much more specific. They state clear targets for inflation, the nominal interest rate, the exchange rate, the budget deficit and the debt to GDP ratio. 


\begin{tabular}{|c|c|}
\hline $\begin{array}{l}\text { Inflation } \\
\text { Rate }\end{array}$ & $\begin{array}{l}\text { A Member State has to show a price stability performance that is } \\
\text { sustainable and an average rate of inflation, observed over a period } \\
\text { of one year before the examination, that does not exceed by more } \\
\text { than } 11 / 2 \text { percentages points that of, at most, the three best } \\
\text { performing Member States in terms of price stability. } \\
\text { Inflation shall be measured by means of the consumer price index } \\
\text { on a comparable basis, taking into account differences in national } \\
\text { definitions. }\end{array}$ \\
\hline $\begin{array}{l}\text { Interest } \\
\text { Rate }\end{array}$ & $\begin{array}{l}\text { Over a period of one year before the examination, a Member State } \\
\text { has to have an average nominal long-term interest rate that does not } \\
\text { exceed by more than } 2 \text { percentage points that of, at most, the three } \\
\text { best performing Member States in terms of price stability. } \\
\text { Interest rates shall be measured on the basis of long-term } \\
\text { government bonds or comparable securities, taking into account } \\
\text { differences in national definitions. }\end{array}$ \\
\hline $\begin{array}{l}\text { Exchange } \\
\text { Rate }\end{array}$ & $\begin{array}{l}\text { A Member State has to respect the normal fluctuation margins } \\
\text { provided for by the exchange-rate mechanism of the European } \\
\text { Monetary System without severe tensions for at least the last two } \\
\text { years before the examination. } \\
\text { In particular, the Member State shall not have devalued its currency } \\
\text { on its own initiative for the same period. }\end{array}$ \\
\hline $\begin{array}{l}\text { Government } \\
\text { deficit }\end{array}$ & $\begin{array}{l}\text { The general government deficit may not exceed } 3 \% \text { of GDP, or } \\
\text { should be falling substantially or only be temporarily above though } \\
\text { still close to this level. }\end{array}$ \\
\hline $\begin{array}{l}\text { Government } \\
\text { debt ratio }\end{array}$ & $\begin{array}{l}\text { Gross general government debt may not exceed } 60 \% \text { of GDP at } \\
\text { market prices, or must at least show a sufficiently diminishing (rate) } \\
\text { and approaching the reference value at a satisfactory (rate). }\end{array}$ \\
\hline
\end{tabular}

Thus a fixed exchange rate regime vis-à-vis the euro (including a euro currency board) would be consistent with the Maastricht criteria, as would a floating exchange rate regime that does not breach the normal fluctuation margins, currently $15 \%$. 


\section{SUERF STUDIES}

1. G.M.M. Gelauff and C. den Broeder, Governance of Stakeholder relationships; The German and Dutch experience Amsterdam, 1997. ISBN 90-5143-024-8.

2. Rolf Skog, Does Sweden Need a Mandatory Bid Rule? A Critical Analysis, Amsterdam, 1997. ISBN 90-5143-025-6.

3. Corporate Governance in Central and Eastern Europe; -Transition Management is a Tough Job Two papers. Amsterdam, 1998.

ISBN 90-5143-027-2.

Debora Revoltella, Financing Firms in East European Countries: an Asymmetric Information and Agency Costs Approach.

Peter H. Haiss and Gerhard Fink, Seven Years of Financial Market Reform in Central Europe.

4. Joseph Bisignano, Towards an Understanding of the Changing Structure of Financial Intermediation; An Evolutionary Theory of Institutional Survival, Amsterdam, 1998. ISBN 90-5143-026-4.

5. David T. Llewellyn, The New Economics of Banking, Amsterdam, 1999. ISBN 90-5143-028-0.

6. John Calverley, Sarah Hewin, and Kevin Grice, Emerging Stock Markets after the Crisis, Amsterdam, 2000. ISBN 90-5143-029-9.

7. Strengthening Financial Infrastructure: Deposit Insurance and Lending of Last Resort. Two papers. Amsterdam, 2000. ISBN 90-5143-030-2.

Richard Dale, Deposit Insurance in Theory and Practice. Christian de Boissieu and Franco Bruni, Lending of Last Resort and Systemic Stability in the Eurozone.

8. Cem Karacadag and Michael W. Taylor, The New Capital Adequacy Framework. Institutional Constraints and Incentive Structures. Vienna, 2000. ISBN 3-902109-00-9.

9. Miguel Sebastián and Carmen Hernansanz, The Spanish Bank's Strategy in Latin America. Vienna, 2000. ISBN 3-902109-01-7.

10. M.M.G. Fase and W.F.V. Vanthoor, The Federal Reserve System Discussed: A Comparative Analysis. Vienna, 2000. ISBN 3-902109-02-5.

See also www.suerf.org 